\title{
Transcription Factor 7
}

National Cancer Institute

\section{Source}

National Cancer Institute. Transcription Factor 7. NCI Thesaurus. Code C97908.

Transcription factor 7 (384 aa, $42 \mathrm{kDa}$ ) is encoded by the human TCF7 gene. This protein is involved in both thymocyte survival and the regulation of transcription. 